ПАНЧЕНКО С. В., д.т.н., професор, ректор Українського державного університету залізничного транспорту

\title{
Розвиток наукової діяльності в Українському державному університеті залізничного транспорту
}

85-річний період існування університету відзначився бурхливим розвитком наукової діяльності.

Друга половина минулого сторіччя відзначилася інтенсивним постачанням до лабораторій вишу нового обладнання, на всіх кафедрах виконувалися науководослідні роботи. У лабораторіях $\mathrm{i}$ на кафедрах працювало понад 330 штатних співробітників, як сумісники працювали 180 викладачів, 60 аспірантів та понад 500 студентів, що відповідало розмірам типового науково-дослідного інституту.

Найбільш ефективно працювали галузеві науководослідні лабораторії. У штаті, наприклад, тепловозної у середині 70-х і до середини 80-х років працювало до 40 одиниць персоналу, обладнання складалося 3 різноманітних стендів (у тому числі діючих дизелів і компресорів), на яких було можливим відпрацьовувати зміни у конструкції, досліджувати надійність тих чи інших вузлів. У ГНДЛ залізобетонних шпал кафедри будівельних матеріалів було придбано унікальну 3 великим обсягом термобарокамеру, лінію по виготовленню залізобетонних виробів.

Роки розпаду СРСР та становлення України як держави виявилися важкими для вчених інституту. Спад у перевезеннях, зміни валют, інфляційні процеси різко знизили потребу у наукових дослідженнях. Лише починаючи з другої половини 1993 року поступово почала налагоджуватись дослідницька діяльність тепер уже для потреб Укрзалізниці та Міністерства транспорту.

У непростий перехідний період $1992-1996$ років вишу вдалося зберегти, на відміну від багатьох інших вишів України, наукову базу та стабілізувати обсяги наукових досліджень.

Останніми роками науково-дослідна діяльність кафедри автоматики та комп'ютерного телекерування рухом поїздів факультету автоматики телемеханіки і зв'язку значним чином спрямована на впровадження мікропроцесорних систем керування та контролю на залізничному транспорті, а також підвищення їх експлуатаційної надійності та безпеки функціонування. Зокрема, в $2013-2014$ pp. фахівцями кафедри проведений комплекс робіт із дослідження функціональної безпеки та електромагнітної сумісності сучасних систем залізничної автоматики (мікропроцесорної та релейно- мікропроцесорної централізації, лічення осей рухомого складу тощо) в рамках їх сертифікації (рис. 1).

Значний обсяг робіт на кафедрі проведений також у напрямку розроблення i впровадження систем автоматичного оповіщення працюючих на коліях, пристроїв контролю та діагностування неоднорідностей електричних ліній, а також заходів щодо підвищення надійності рейкових кіл і точкових колійних датчиків. Науково-прикладні результати діяльності кафедри впроваджені у вигляді систем керування, діагностичних комплексів, нормативної та технічної документації на магістральному i промисловому залізничному транспорті, а також у суміжних відповідальних галузях народного господарства, зокрема в атомній енергетиці.

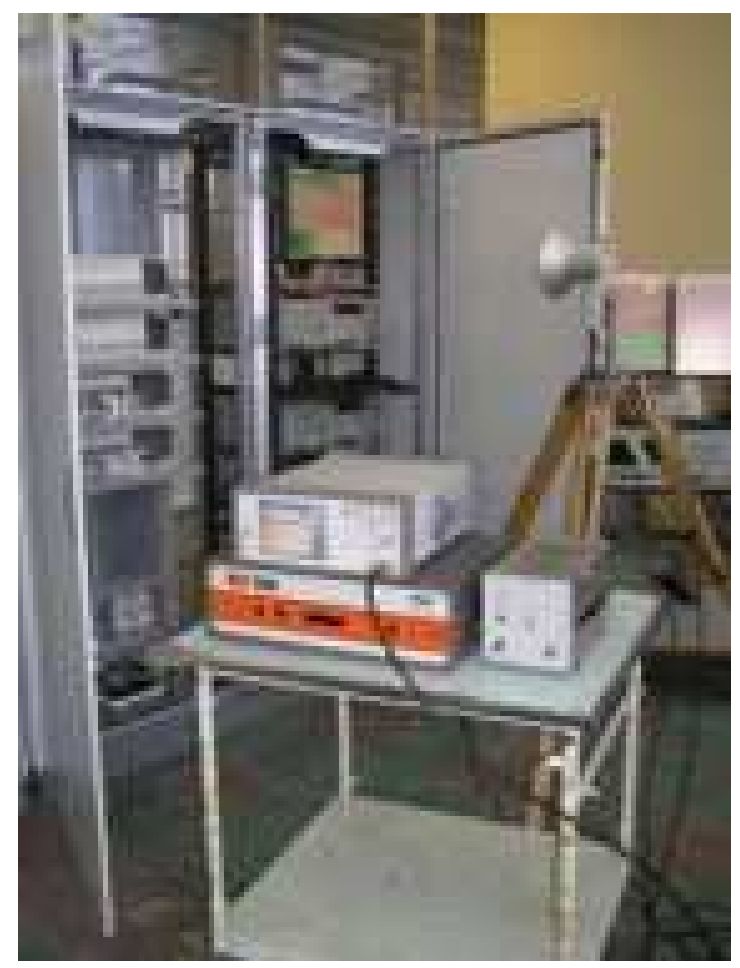

Рис. 1. Випробування системи мікропроцесорної централізації на електромагнітну сумісність

() С.В. Панченко, 2015 
Основними напрямами діяльності кафедри телекомунікаційних технологій з метою підвищення транспортного зв'язку є розвиток теорії ефективності використання та якості функціонування телекомунікацій, на основі якої здійснюється розробка телекомунікаційних систем та мереж загального нових методів обробки інформації, наукове обгрунтування математичних моделей складових телекомунікаційних систем та удосконалення користування, інтелектуальних систем, а також систем та мереж технологічного зв'язку залізничного транспорту (рис. 2).

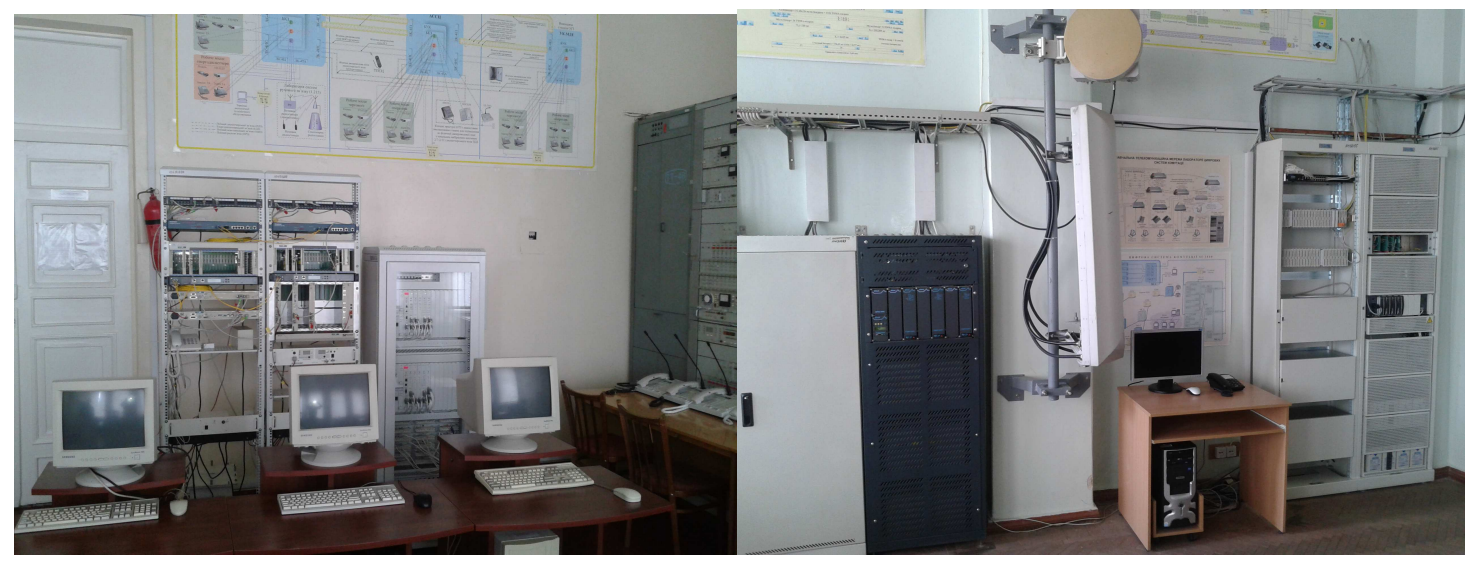

Рис. 2. Лабораторія цифрових систем передачі даних

Кафедра спеціалізованих комп'ютерних систем та галузева науково-дослідна лабораторія мікропроцесорних засобів автоматизації об'єктів залізничного транспорту виконує наукові дослідження за такими напрямами:

— аналіз станів і тенденцій розвитку архітектур розподілених систем обробки даних i методів підвищення їх надійності та відмовостійкості в світлі сучасних інформаційних і мікроелектронних технологій;

— вирішення проблем що виникають при функціонуванні розподілених обчислювальних систем використовуючих GRID технології;

— комп'ютерні та інформаційно-керуючі системи підвищення безпечності транспорту та транспортної інфраструктури;

- стандартизація, сертифікація та інформаційновимірювальні системи метрологічного забезпечення в галузі.

На кафедрі одержали подальший розвиток:

— імітаційна модель пакетного планування завдань і вибору ресурсів в ієрархічних розподілених обчислювальних системах;

- удосконалена модель обліку i контролю електроенергії інформаційно-вимірювальним комплексом, що дозволила ураховувати динамічний характер завантаження фідера живлення;

- методи проектування та структурного синтезу редукованих МП-автоматних моделей діагностичних систем (ДС), засновані на інтерполяційних методах стиснення еталонних геометричних образів діагностичних систем i алгоритмів функціонування модулів управління МП-автоматних моделей у вигляді логічних схем алгоритмів;

- спосіб підвищення точності обліку й контролю електроенергії інформаційно-вимірювальним комплексом;

- пристрій підвищення точності обліку i контролю електроенергії інформаційновимірювальним комплексом (рис. 3).

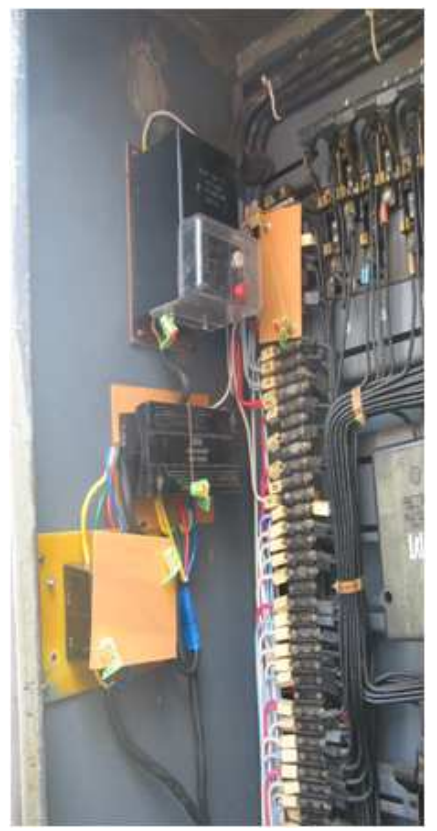

Рис. 3. Пристрій підвищення точності обліку і контролю електроенергії інформаційновимірювальним комплексом 
Основним напрямком наукової діяльності кафедри обчислювальної техніки та систем управління є підвищення безпеки руху на залізничному транспорті. За результатами наукової діяльності:

— розроблено інформаційно-логічну структуру управління ризиками на сортувальній гірці, що забезпечує підтримку та виконання основних дій, спрямованих на виявлення, оцінку й управління ризиками;

- сформовано науковий підхід, який дає змогу підійти до рішення задач підвищення ефективності експлуатації сортувальної гірки 3 урахуванням управління безпекою розформування составів та впливу людського фактору;

$$
\text { - розроблено процедуру вироблення }
$$
цілеспрямованих управляючих впливів на керовану систему на основі сценарної логіко-ймовірнісної моделі ризику виникнення порушень безпеки функціонування сортувальної гірки;

- удосконалено ергатичну систему управління безпекою функціонування сортувальної гірки, що дає змогу підвищити ефективність та надійність роботи операторів;

— розроблено імітаційну модель поширення ландшафтної пожежі уздовж транспортної інфраструктури з можливістю обчислення температури та інших характеристик об'ємної зони пожежі, що дає можливість оцінити імовірність виникнення пожежі, прогнозувати шляхи розповсюдження пожежі та цілеспрямовано застосовувати попереджувальні засоби та засоби гасіння пожежі.

У перспективі отримані розробки планується поширити на всі структурні підрозділи залізничного транспорту.

3 метою створення вітчизняних технологій виробництва нових матеріалів для транспортної галузі фахівцями кафедри будівельних, колійних вантажнорозвантажувальних машин будівельного факультету, починаючи 32012 року, був спроектований та виготовлений дослідницький стенд для отримання наночастинок вуглецю електродуговим способом (рис. 4). Конструкція та основні параметри стенду $є$ запатентованими і не мають світових аналогів.

Стенд дозволяє виробляти для дослідницьких цілей вуглецеві нанотрубки та фулерени, які в подальшому можуть бути застосовані як легуючі елементи при виготовленні мастильних, антифрикційних та зносостійких матеріалів нового покоління для транспортного машинобудування України.

Основними напрямами досліджень при використанні розробленого стенду є:

- установлення раціональних режимів отримання наночастинок та створення рекомендацій щодо їх промислового виробництва;

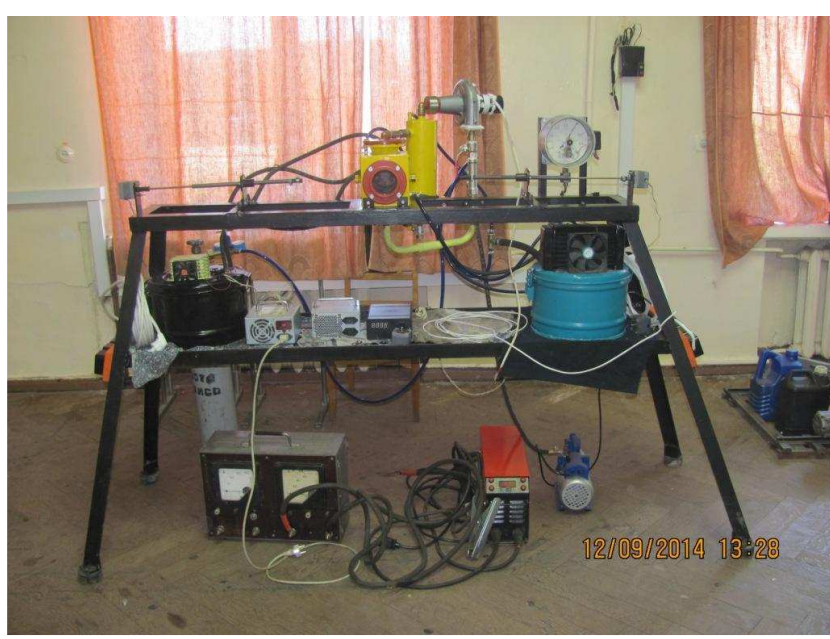

Рис. 4. Дослідницький стенд для отримання структурованих наночастинок вуглецю

- дослідження параметрів та властивостей отриманих наночастинок та встановлення імовірних напрямків їх застосування в транспортному машинобудуванні;

- створення та впровадження наноматеріалів для транспортної галузі із використанням наночастинок вуглецю.

Комплексне вирішення завдань, що висуваються в межах перелічених напрямів досліджень дозволить у найближчій перспективі отримати низку ресурсозберігаючих технологій для транспортної галузі України, що неодмінно підвищить іiі конкурентоспроможність на світовому ринку.

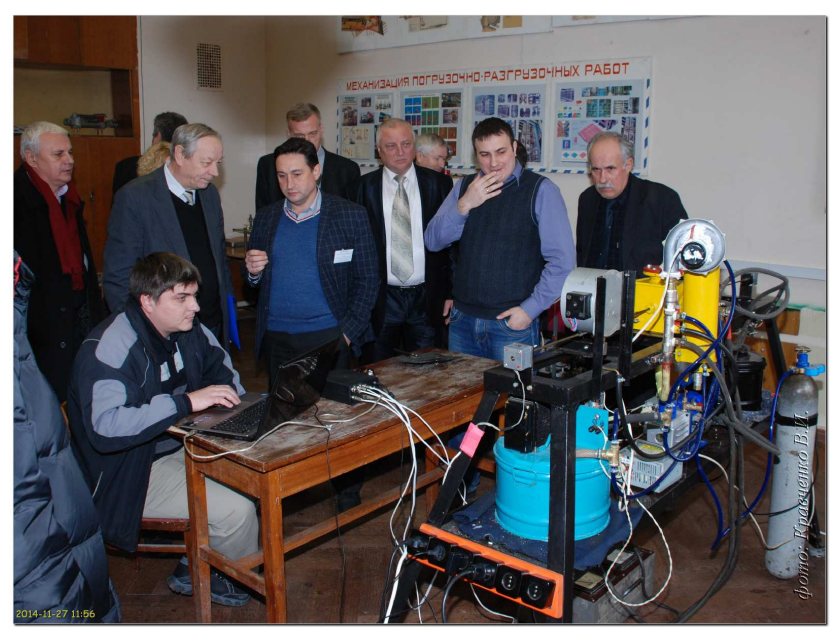

Рис. 5. Учасники міжнародної науково-технічної конференції «Нові технології, обладнання, матеріали в будівництві і на транспорті», присвяченої 80-річчю кафедри БКВРМ, обговорюють конструкцію стенду 
І Н Ф О Р М А Ц Й Н О - К Е Р У Ю Ч І С ИС Т Е И Н А З А Л І 3 Н И Ч Н О М У Т Р АН С П О Р Т І

На кафедрі будівельних матеріалів, конструкиій ma споруд наукову школу колоїдно-хімічного будівельного матеріалознавства, створену почесним професором університету А. М. Плугіним, нині очолює професор А. А. Плугін. Основними фундаментальними і прикладними напрямками цієї школи є: розвиток теорії твердіння мінеральних в'яжучих з урахуванням електроповерхневих властивостей i явищ (електрогетерогенна теорія твердіння); механізм безнапірної водопроникності бетону; механізм наднормативної довготривалої та повторюваної швидконатікаючої повзучості бетону; розвиток теорії складу бетону; розвиток теорії корозії і електрокорозії бетону та залізобетону 3 урахуванням електроповерхневих властивостей i явищ. Були отримані такі розробки: склади бетону підвищеної водонепроникності, тріщиностійкості, електрокорозійної стійкості, цементні й полімеркомпозиційні склади для ремонту, гідроізоляції та захисту конструкцій і споруд, конструктивні й технологічні рішення ремонту, підсилення і захисту конструкцій та споруд тощо (рис. 6). У $2011-12$ рр. видавництвом НАН України «Наукова думка» було видано 3-х томну монографію професорів А. М. і А. А. Плугіних зі співавторами «Основитеорії твердіння, міцності, руйнування і довговічності портландцементу, бетону і конструкцій із них».

У 2013 р. доцентам О. С. Борзяк і О. А. Плугіну було присуджено премію Президента України для молодих учених за роботу «Електрообробка та захист від електрокорозії бетонів, виробів і конструкцій із них» (рис. 7).
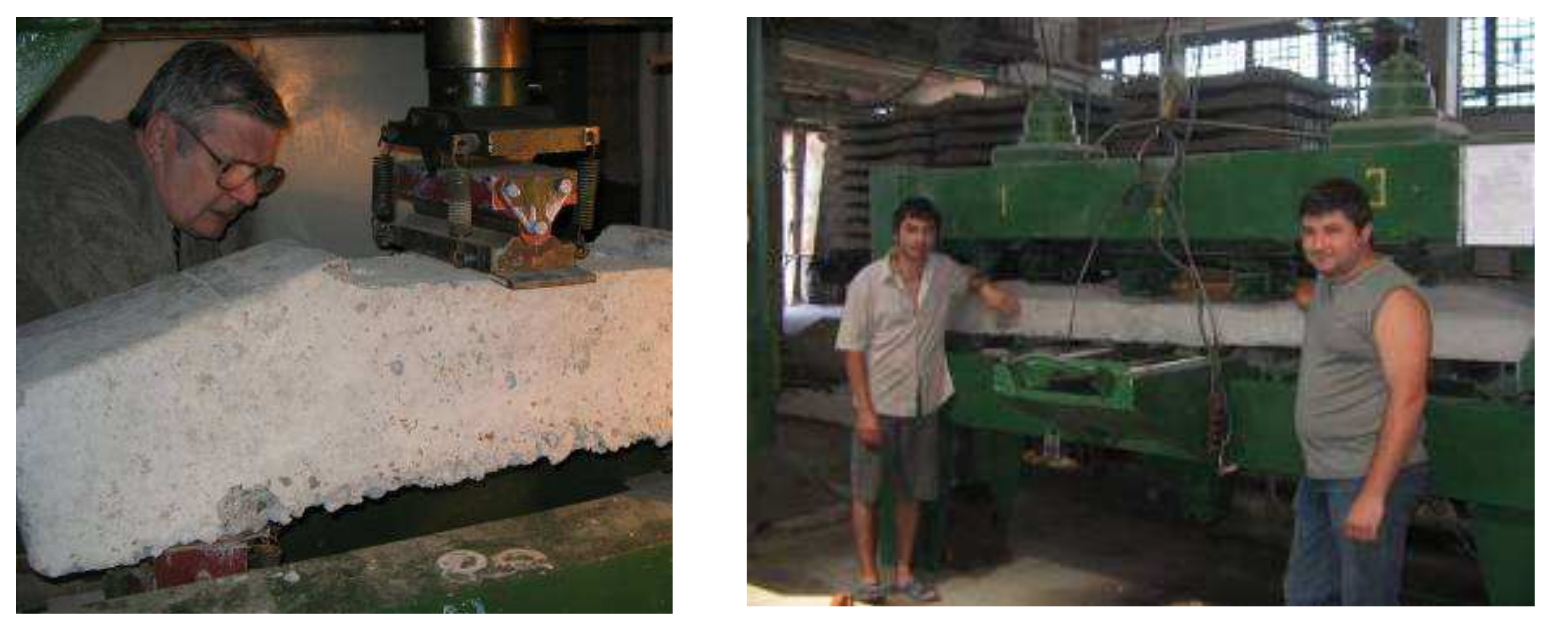

Рис. 6. Під керівництвом проф. А. М. Плугіна аспіранти (тепер доценти) О. А. Дудін та О. В. Романенко проводять дослідження впливу добавок суперпластифікаторів і прискорювачів твердіння на тріщиностійкість залізобетонних шпал (2007р.)
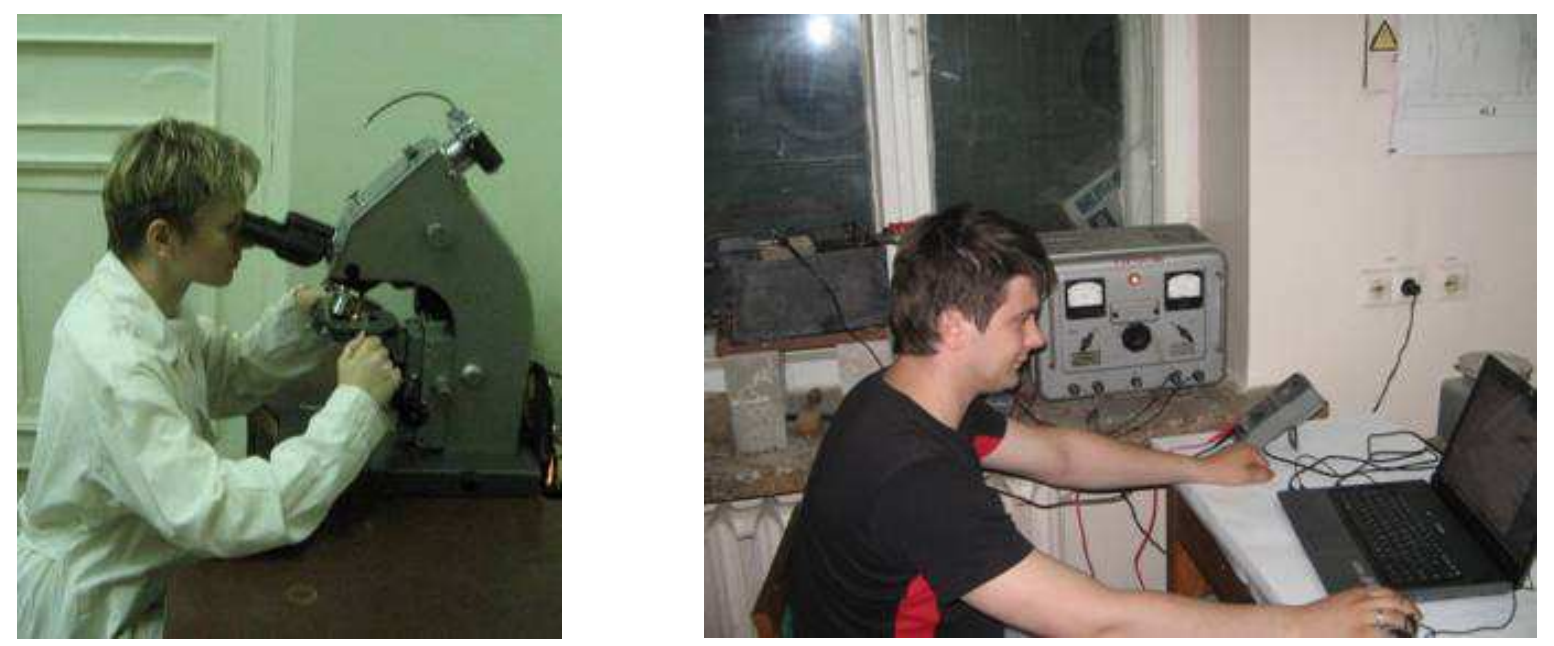

Рис. 7. Аспіранти (тепер доценти) О. С. Борзяк та О. А. Плугін проводять петрографічні та електрометричні дослідження впливу електричного струму на бетон 


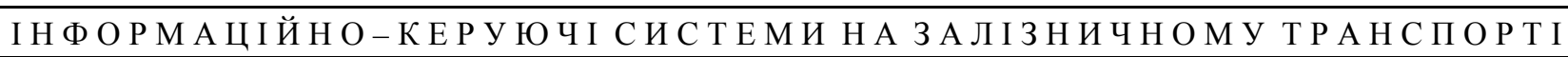

Кафедра економіки та управління виробничим $i$ комериійним бізнесом економічного факультету має власну потужну наукову школу i накопичила величезний досвід проведення наукових досліджень. За останні роки були виконані роботи за тематикою «Забезпечення конкурентоспроможності промислових підприємств в умовах міжнародних транспортних коридорів», «Забезпечення конкурентоспроможності залізничного транспорту в логістичній системі", «Розробка техніко-економічних розрахунків та пропозицій по перевлаштуванню залізобетонних мостів на коліях транспортних коридорів».

Дотримуючись традицій наукової школи, подальша науково-дослідна робота кафедри пов'язана 3 вирішенням таких актуальних проблем вітчизняного залізничного транспорту як: інтеграція залізничного транспорту Україні в світову промислово-логістичну систему, розвиток високотехнологічного бізнесу промислово-логістичних кластерів в умовах євроінтеграції, розвиток соціально-господарської відповідальності підприємств залізничного транспорту (у тому числі на основі формування культури і системи мотивації ресурсозбереження), забезпечення інноваційного розвитку залізничного транспорту, управління ризиками залізничного транспорту в системі національної безпеки країни.

Нині на кафедрі експлуатаиії та ремонту рухомого складу мехнічного факультету для проведення досліджень 3 надійності, економічності, теплотехнічних характеристик локомотивних енергетичних установок працює лабораторія механічного обладнання локомотивів, де знаходиться дизель-генераторний стенд на базі дизеля 8ЧН26/26 (6Д49) та тягового генератора типу ГПЗ00БУ. Цей стенд дозволяє в комплексі проводити дослідження в сфері локомотивних енергетичних установок, систем їх керування, а також електричних машин та апаратів.

У лабораторії проводяться роботи 3 дослідження елементів ресорного підвішування екіпажної часини локомотивів та моторвагонного рухомого складу. Для цього в наявності є необхідні стенди 3 випробування циліндричних пружин, листових ресор, гумовометалічних елементів, гідравлічних i фрикційних гасників коливань.

Для потреб локомотивних депо та проведення наукових досліджень у лабораторії розроблено випробувально-дослідницькі стенди 3 окремих вузлів паливної апаратури тепловозів, зокрема форсунок, паливних насосів високого тиску, їх плунжерних пар. Особливістю цих стендів $є$ застосування у них мікропроцесорних систем для вимірювання параметрів та контролю процесу випробувань, що дозволяє 3 більш високою точністю аналізувати процеси у цих вузлах, здійснювати моделювання та розробляти ефективні алгоритми їх діагностування (рис. 8).

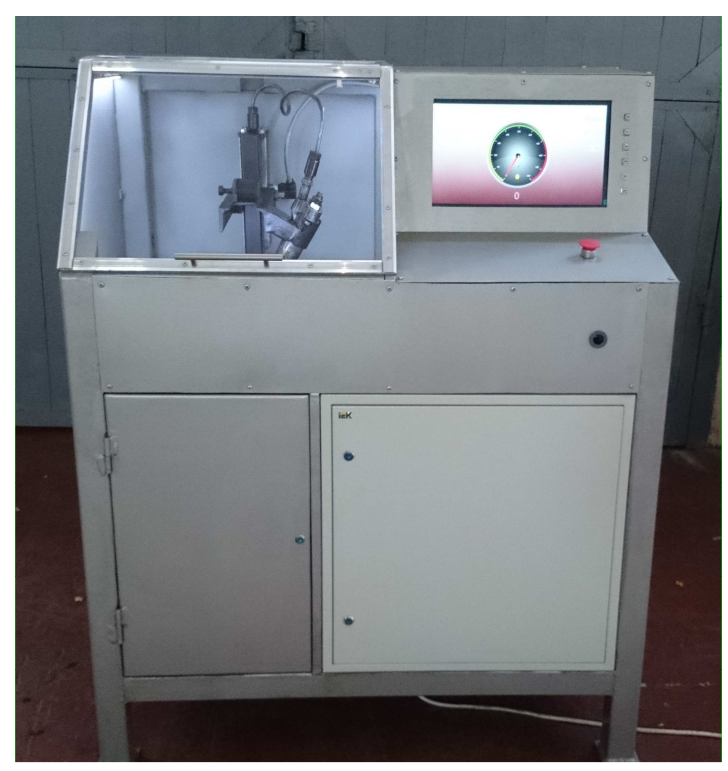

Рис. 8. Зовнішній вигляд мікропроцесорного автоматизованого стенду для контролю форсунок тепловозних дизелів

Для проведення досліджень і моделювання систем діагностування та електронних приладів, що нині широко застосовуються на локомотивах нового покоління вітчизняного та імпортного виробництва, працює лабораторія діагностики та електронного обладнання локомотивів. На іiі базі проводиться не тільки розробка нових, а і модернізація, перевірка й випробування існуючих приладів і систем.

Як один із напрямків наукової роботи кафедри розробка та впровадження автоматизованих робочих місць підприємств локомотивного господарства i тренажерних комплексів для навчання, підвищення кваліфікації й контролю практичних і теоретичних знань машиністів локомотивів та їх помічників на базі сучасної елементної бази та електроннообчислювальної техніки.

Науково-дослідна

робота

кафедри автоматизованих систем електричного транспорту спрямована на розв'язання потреб виробництва. Так, під керівництвом професора Я. В. Щербака, в результаті комплексних досліджень в області статичних перетворювачів та їх систем автоматичного регулювання, розроблені основні методичні підходи до створення конкурентноспроможних перетворювачів енергії. Як результат, на замовлення Харківського державного приладо-будівного заводу ім. Т. Г. Шевченка виконана розробка та впроваджено в серійне виробництво пускорегулюючі перетворювачі для систем освітлення рухомого складу (рис. 9).

Цими перетворювачами обладнувались вагони нових електропоїздів холдингової компанії „Луганськтепловоз”. 


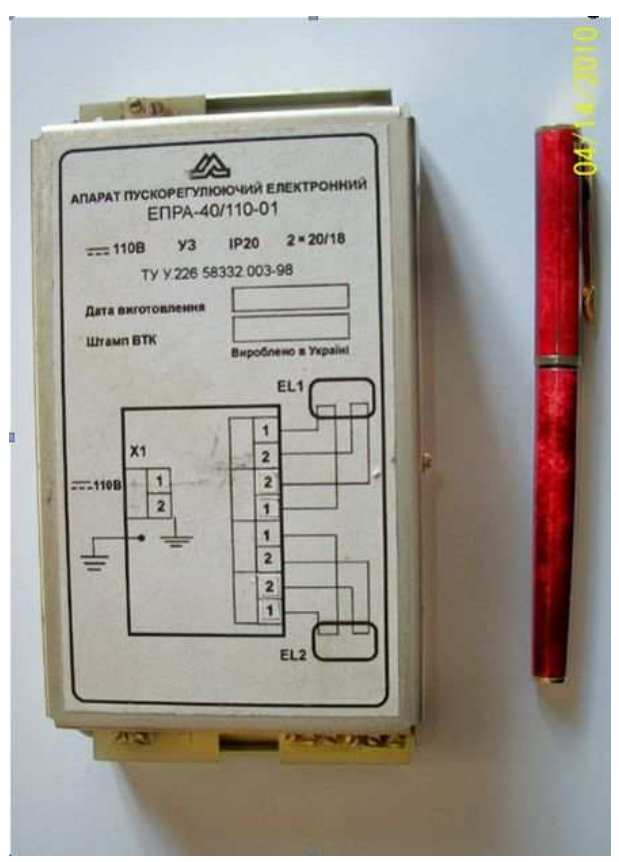

Рис. 9. Пускорегулюючі перетворювачі для систем освітлення рухомого складу

Розроблено та впроваджено в складі електричного обладнання трамвайних вагонів Т3 та Т3М м. Харкова: статичний перетворювач для живлення власних потреб, трифазний перетворювач для живлення асинхронного двигуна системи вентиляції та пускорегулюючий перетворювач для живлення люмінесцентних ламп. Разом з ДП НДІ "ХЕМЗ" виконана розробка діодних блоків БСД-1 і БСД-2 для випрямних установок тягових підстанцій постійного струму. Об'єднання силової частини 3 системою діагностики стану діодів надає цим блокам більшої універсальності при застосуванні в порівнянні 3 блоками BEI (м. Москва).

Використання даних діодних блоків (рис. 10) дозволяє підвищити надійність і коефіцієнт потужності випрямляючої установки провести модернізацію випрямляючих установок тягових підстанцій „Дубово” Слав’янської ЕЧ, “Зелений клин” Краснолиманської ЕЧ Донецької залізниці, та ,, Букіно” Оснав’ янської ЕЧ Південної залізниці. Планується подальше застосування даних діодних блоків на Південній залізниці.

Інтенсивно ведуться наукові дослідження 3 покращення електромагнітної сумісності тягових підстанцій постійного струму залізниць і міського електричного транспорту з живильною та контактними мережами. В основу досліджень покладено застосування спеціальних замкнутих систем автоматичного регулювання вхідних i вихідних координат керованого перетворювача електричної енергії. Теоретичні основи таких систем створені проф. Я.В. Щербаком.

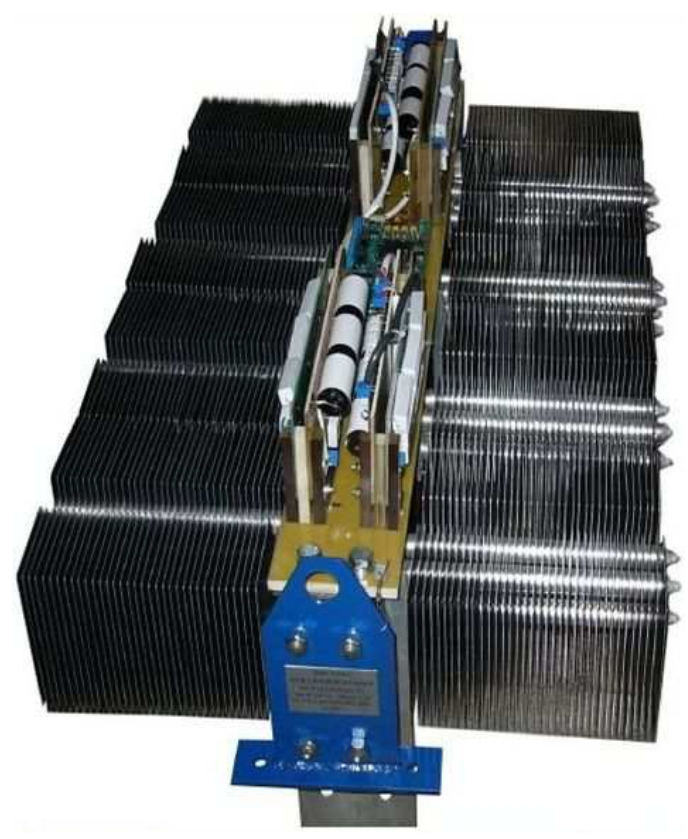

Рис. 10. Діодні блоки для випрямних установок тягових підстанцій постійного струму

Під керівництвом професора Ю. І. Гусевського виконані розробки нових структур i принципів управління тягового асинхронного електроприводу маневрового тепловоза потужністю 800 к. с., що створювався холдинговою компанією „Луганськтепловоз” на замовлення Укрзалізниці.

Виконано розробку й дослідження перспективного тягового електроприводу електровозу, побудованого по структурі «Автономний трирівневий інвертор напруги - двофазний асинхронний електродвигун (АІН-АД)”. Досліджена сумісна робота 2-х та 3-х структур АІН-АД, одержано точні аналітичні залежності для розрахунків енергетичних показників системи АІН-АД, які раніше виконувались методом неперервної апроксимації. Науково обгрунтовано методи поліпшення умов електромагнітної сумісності тягового асинхронного електроприводу 3 джерелом живлення, запропоновані методи зменшення амплітуди пульсацій і підвищення частоти вхідного струму АIM та покращення режиму роботи вхідного фільтра.

Великий обсяг робіт зі створення статичного перетворювача для живлення власних потреб електровоза та напівпровідникової системи управління тягового двигуна шахтного електровоза виконано доцентами О. І. Семененко і В. С. Нікуліним.

Групою спеціалістів кафедри під керівництвом доцента C. I. Яцька проводяться дослідження в напрямку ресурсо - та енергозбереження на рухомому складі залізниці та метрополітені i виконується технічне супроводження створення вітчизняних електропоїздів. 
Під керівництвом доцента С. Г. Буряковського виконано розробку й дослідження нових систем електроприводу стрілочного переводу.

Розширення області досліджень, високий рівень їх виконання та потреби в постійному обміні новітньою інформацією, зумовило створення на кафедрі постійно діючого семінару „Проблеми перетворення електроенергії в системах електричного транспорту” 3 комплексної проблеми „Наукові основи електроенергетики”, яка керується НАН України.

Кафедри факультету управління процесами перевезень здійснюють таку наукову діяльність:

- формування та удосконалення технологій управління підприємствами залізничного транспорту, які задіяні у всіх видах комерційної і вантажної роботи, на основі застосування сучасних інтелектуальних методів;

— підвищення ефективності роботи вантажних станцій на основі використання теорії масового обслуговування, теорії запасів, теорії компромісних ситуацій, основ транспортного маркетингу та логістики;

— комплексна механізація i автоматизація технології вантажно-розвантажувальних робіт, кріплення вантажів у вагонах (у т.ч. військова техніка); колій;

— взаємодія станцій примикання та під’їзих

- удосконалення технології роботи прикордонних передавальних станцій;

— взаємодія вантажних станцій з іншими видами транспорту;

— ресурсозберігаючі технології на станціях; організація роботи залізничних станцій в міжнародних транспортних коридорах; організація митного контролю на залізничних станціях; удосконалення конструкції сортувальних пристроїв; технологічна безпека при організації руху поїздів; удосконалення конструкції елементів залізничних станцій та вузлів;

$$
\text { - методи формування інтелектуальних }
$$
залізничних транспортних систем;

- розробка автоматизованої технології оперативного регулювання составоутворення пасажирських поїздів;

- розробка автоматизованої технології місцевої роботи на основі формування контактного графіку;

— формування ефективної моделі перевізного процесу в умовах реформування галузі.

Університет брав участь у формуванні Державної програми розвитку високошвидкісного залізничного транспорту України, Державної програми підвищення безпеки руху на залізницях України, Програми підвищення рівня механізації на залізничному транспорті, а також був основним розробником Державної програми розвитку залізничної автоматики на промисловому транспорті України та Державної цільової програми забезпечення безпеки перевезення небезпечних вантажів на 2011 - 2020 роки.

Нині основними замовниками госпдоговірних НДР $\epsilon$ підприємства Укрзалізниці $(30-40 \%$ загального обсягу щорічно), Харківський метрополітен (10$20 \%$ ). Останні роки обсяг наукових робіт складає близько 3 млн. грн.на рік. Щорічно береться участь у конкурсному відборі проектів наукових досліджень, що фінансуються з державного бюджету України.

Незважаючи на тривалий період становлення служби інтелектуальної власності України, відсутність фінансування, вдалося припинити спад у винахідницькій діяльності в університеті. За роки незалежності було направлено до Держпатенту України близько 300 заявок на винаходи та корисні моделі та отримано 260 патентів.

Щорічно викладачами та науковими співробітниками університету опубліковується близько 4 підручників, 18 навчальних посібників, 16 монографій, 650 статей, 700 тез доповідей. Два збірники наукових праць університету та два журнали включені до переліку наукових видань ВАК, у яких можуть друкуватися основні результати дисертаційних робіт.

Останніми роками збільшилася кількість студентів, що беруть участь у наукових конференціях.

До позитивних змін у науковій діяльності слід віднести активізацію роботи галузевих науководослідних лабораторій та створення протягом останнього часу двох нових ГНДЛ: економіки залізничного транспорту та електричного моторвагонного рухомого складу. Нині кількість працюючих ГНДЛ налічує 17 із яких 3 атестовані.

П'ять років поспіль УкрДУЗТ $є$ базовою організацією 3 проведення Всеукраїнського конкурсу наукових студентських робіт по розділу "Залізничний транспорт та спеціальна техніка ". За ці роки було подано на конкурс 330 робіт наших студентів: 3 них 57 робіт стали переможцями Всеукраїнського конкурсу. Останніми роками студенти університету значно активніше беруть участь у наукових заходах в інших вишах i містах України: Києві, Дніпропетровську, Одесі, Львові. Усі студенти-переможці наукових заходів отримують від керівництва університету грамоти й дипломи переможців, які урочисто вручаються на засіданнях Ради факультетів та засіданнях Ради університету.

Поступила 19.06.20152.

Sergiy Panchenko, Rector of Ukrainian State University of Railway Transport, Dr. of tech. science, professor, Ukrainian State University Railway Transport, Kharkiv, Ukraine. 